\title{
Consumers' perceived risks associated with purchasing on a branded web site: The mediating effect of brand knowledge
}

\author{
C. Boshoff ${ }^{\star}$, C. Schlechter and S.-J. Ward \\ Department of Business Management, University of Stellenbosch, \\ Private Bag X1, Stellenbosch 7600, Republic of South Africa \\ cboshoff@sun.ac.za
}

Received October 2009

\begin{abstract}
Research concerning online consumer behaviour has found that consumers are more inclined to utilise the Internet for information searching rather than actual purchasing. One reason proposed for this state of affairs is that potential buyers perceive buying on the Internet as a risky endeavour.
\end{abstract}

The unique purchasing decision in an online environment is different from a traditional purchasing environment and as a result online transactions differ from the traditional 'bricks-and-mortar' environment. These differences may lead to risk perceptions among potential purchasers that are unique to online purchase intention. This study assesses the impact of the perceived risks associated with intention to purchase online from a well-established, branded web site on purchasing intentions. A secondary objective of the study was to assess whether the consumer's brand knowledge (brand awareness and brand image) mediates the impact of risk perceptions on the intention to purchase from the web site.

It was found that both Performance risk and Social risk exert a strong negative influence on Intentions to purchase on a branded web site. Personal risk, however, do not impact on intentions to purchase on a branded web site. Furthermore, it was found that Brand knowledge does act as a mediating variable between Performance risk and Intentions to buy on a branded web site. Brand knowledge, however does not mediate the impact of Social risk on intentions to buy on a branded web site.

*To whom all correspondence should be addressed.

\section{Introduction}

Although the origins of the technology can be traced back to 1958, the Internet, initially known as the "International electronic network", was started in 1986 (Pallab, 1996 as cited in Tan, 1999). Over time the Internet has evolved away from its initial role as a channel of communication for the military to increasing commercial use. Today the Internet, in a consumer marketing context, is effectively used in four major ways, namely:

- $\quad$ as a retail distribution channel;

- $\quad$ as a marketing communication channel or tool;

- $\quad$ as a customer relationship management tool; and

- $\quad$ as marketing research tool or a source of information.

As a result of these uses the Internet today offers consumers not only access to an extensive amount of information but is also an alternative way of making purchases. However, the high growth predictions offered in the late 1990`s (Jarvelainen \& Puhakainen, 2004; Chen \& He, 2003) have not really materialised. Mayo, Helms and Inks (2006: 271) put it this way: "A key concern in e-commerce continues to be the slower-than-current-anticipated growth rate in consumer purchases..." Estimates of the market share of online purchasing range from under $2 \%$ of total retail spending (Retail Forward, 2003 as cited in Swinyard \& Smith, 2003) to about $10 \%$ in the British retail market (IMRG, 2007 as quoted by totalwebsolutions.com), which suggests that consumers have been slow to adopt online purchasing ( $\mathrm{Su}, 2008)$.

Those who anticipated faster growth of Internet purchasing are confronted by the reality that nearly two thirds of Internet users have used the Internet to research potential purchases online, but they have yet to purchase over the internet (Yang, Lester \& James 2007). In other words, consumers are more likely to do pre-purchase information searching on the Internet rather than actual purchasing (Forsythe \& Shi, 2003).

One plausible explanation for this relatively slow growth in online purchasing is that consumers perceive the act of purchasing online to be a risky endeavour, and that this risk could affect their likelihood of purchase (Wood \& Sheer, 1996). 
Although some work has been done on the role of trust (Stewart \& Malaga, 2009; Delgado \& HernandezEspallardo, 2008; Suh \& Han, 2003; Tan \& Thoen, 20002001) and risk (Gupta, Su \& Walter, 2004) in ecommerce, limited research has been done on the impact of individual risk types. Some of the work on risk perceptions in ecommerce is also not beyond reproach. Gupta et al (2004) for instance measured risk perceptions using a composite measure of four single items of four different types of risks (financial, performance, psychological and social risk) and one 'overall' risk item. Given the diverse nature of these risk-types it is not surprising that they reported very low reliability co-efficients for this measure. In this study we use multi-item scales to measure each risk type and report excellent internal consistency indices for all risk types.

A further gap in the literature is the fact there is a paucity of research concerning risk related to branded and non-branded (or generically-branded) retailer websites.

The purpose of this study was therefore to investigate the perceived risks associated with intention to purchase online using multi-item instruments (see Appendix A) that demonstrate sufficient evidence of both reliability and validity (see Table 1).

The primary contribution of this study, however, lies in extending the research relating to perceived risk by examining the influence of brand knowledge on perceived risk by investigating whether this variable can act as a mediating variable influencing consumer intention to purchase on a branded website (as opposed to a non-branded or generically-branded web site).

\section{The role of risk in purchasing behaviour}

Classical consumer behaviour theory and purchasing models suggest that consumers move through a number of stages when deciding whether to make a purchase or not. These stages are: problem recognition, search for information, evaluation of alternatives, purchase, and post-purchase evaluation (Statt, 1997; Schiffman \& Kanuk 2004: 198). As a consumer moves through these stages they are influenced by a variety of extraneous variables, of which one is risk perceptions.

Risk perceptions have been shown to impact on consumer decision-making for both physical products (Dunn, Murphy \& Skelly, 1986) and services (Parasuraman, Zeithaml \& Berry, 1985: 47) and is something a rational consumer will avoid if at all possible - or at least minimize (Bauer, 1960). The concept 'perceived risk' in the context of consumer behaviour refers to a purchasing decision of which both the consequences and the outcomes are uncertain (Bauer, 1960; Cox \& Rich, 1964; Havlena \& DeSarbo, 1991).

\section{Types of risk}

The concept of perceived risk was originally introduced by Bauer (Horton, 1976), who defined risk in terms of the uncertainty and the consequences associated with a consumer's actions (Bauer, 1960; Lu, Hsu \& Hsu, 2005). Consumers are apprehensive when they cannot be sure that purchases will allow them to realise their purchasing goals. Perceived risk can therefore be considered a function of the uncertainty about the potential outcomes of a behaviour and the possible unpleasantness of these outcomes (Forsythe \& Shi, 2003). The amount of risk perceived by the consumer is a function of two main factors, namely the amount at stake in the purchase decision, and the individual's feeling of subjective certainty that he/she will "win" or "lose" all or some of the amount at stake (Cox \& Rich, 1964). The amounts at stake and the purchaser's subjective assessment of the chances of an unfavourable consequence, determine the total amount of risk in any purchase decision (Dowling \& Staelin, 1994). Parallel to the components of perceived risk, uncertainty and consequences, different types of perceived risk exist within overall perceived risk. A number of studies have identified types of perceived risk. The most common types of risk that have been identified include functional, physical, financial, time, psychological, and social risk. For any given purchasing decision "overall risk" can thus include any of the above-mentioned six types of risk, and it can be concluded that perceived risk is a multidimensional construct.

For the purposes of this study the different types of risk are operationalised as:

- $\quad$ Performance risk (also referred to as functional risk) is defined as the uncertainty and the consequence of a product not functioning at some expected level (Huang, Shrank \& Dubinsky, 2004).

- Physical risk refers to the potential threat to an individual's safety, physical health, and well-being (Lu, Hsu \& Hsu, 2005).

- $\quad$ Financial risk is defined as the probability of monetary loss associated with purchasing a product (Huang et al., 2004), as well as the possibility that one's confidential financial information may be misused by others (Forsythe \& Shi, 2003).

- Social risk reflects the disappointment in the individual by friends and family in case of a poor product or service choice (Ueltschy, Krampf \& Yannopoulos, 2004).

- Psychological risk reflects an individual's disappointment in oneself in case of a poor product or service choice (Ueltschy et al., 2004).

- Time risk refers to the probability that a purchase results in loss of time to purchase or retain the product (Chen \& He, 2003) as well as the time and effort lost in returning or exchanging the product, and any technological problems such as a slow website server (Hassan, Kunz, Pearson \& Mohamed, 2006).

Previous research has shown that consumers' perceive risks associated with purchasing, and risk is therefore likely to affect purchase intention (Wood \& Sheer, 1996). Purchase intention is the consumer's plan whether to participate in a transaction or not to and in this study, online purchase intention refers to an intention to transact with an online 
retailer using a website. This intention will, however, be influenced by how the consumer intends dealing with risk perceptions.

\section{Dealing with risk}

Consumers deal with risk in a variety of ways (Hoffman \& Bateson, 1997). Some of the tactics that marketers can use to reduce risk include providing general or specific information, guarantees/warranties, money-back offers, endorsements, and cultivating a comforting store image (Mitchell \& Boustani, 1992: 21; Solomon, 1992: 372; Hoffman \& Bateson, 1997: 87; Schiffman \& Kanuk, 1997: 185). According to Roselius (1971) other methods of risk reduction include endorsements, brand loyalty, major brand image, private testing, store image, free sample, money-back guarantee, government testing, shopping, expensive model, and word-of-mouth. In the online environment return policies, privacy disclosure and assurances of security encryption are risk all reliever tactics that are not only important but unique to this trading platform (Delgado \& Hernandez-Espallardo, 2008).

These risk reliever tactics can be divided into two broad categories: either minimizing the consequences of product/service failure or by enhancing the certainty that the product/service will perform adequately.

In this study branding knowledge (a way of minimising risk) is the focus of the study.

\section{Branding and risk perceptions}

When consumers do not have much knowledge about a product category, the brand name becomes relatively important in their purchase decision (Hsu, Lai \& Chen, 2007). In other words, when consumers are uncertain about a product, they base their choice on what is most familiar or most easily recognised (Jacobs \& de Klerk, 2007), one they are knowledgeable about, one which is popular, well-known or has a strong reputation (Mitchell \& Boustani, 1992). A brand is thus ".. a powerful heuristic cue for evaluations and choice decisions because they often signal intangible offering properties that must otherwise be learned through experience" (Delgado \& Hernandez-Espallardo, 2008).

This contention has been empirically confirmed to also apply to the online environment by Chen and He (2003) and $\mathrm{Su}$ (2008) who found that the greater the consumer's brand knowledge of a particular online retailer, the more likely the consumer is to make an online purchase.

Against the background of the slow adoption of Internet purchasing and the suggested role of risk perceptions the second objective of this study was thus to consider the role that brand knowledge can play as an intervening variable mediating the influence of risk perceptions on purchasing intentions in the online shopping environment.

\section{Objectives}

Many commentators argue that the slow adoption of the Internet as purchasing channel can be attributed to excessive risk perceptions among potential buyers. The primary objective of this study was to assess the validity of this contention. More specifically the objective was determine whether the perceived risks associated with online purchasing will influence a consumer's intention to purchase from a branded website (as opposed to a generically or nonbranded website).

The literature suggests that consumers' risk perceptions are influenced by their brand knowledge (Esch, Langner, Schmitt, \& Geus, 2006). The potential mediating role of brand knowledge in influencing intentions to buy on a branded web site was thus a secondary objective of this study. A further objective will be to compare the results of this study with results reported elsewhere related to the risks perceptions when consumers are asked about buying on a generically-branded web site (Boshoff, Schlechter \& Ward, 2009).

\section{Methodology}

For the purpose of the study a distinction was drawn between a branded web site and a non-branded web site. A well-known online retailer similar to Amazon.com was regarded as a branded web site while a site such as books.com would be regarded as a generically-branded website. To address the research questions, online book retailing was chosen as the study context. A book retailer was chosen since books are one of the most commonly purchased items online (Nielsen, 2005).

\section{Measuring instrument}

Data were collected using a questionnaire adapted and modified from pre-developed scales in previous studies concerning risk by Chen and $\mathrm{He}$ (2003) and Hassan et al. (2006). The instrument measured six type of risk perceptions (26 items), brand knowledge of a branded web site (five items) and intentions to purchase online (four items). Each statement was linked to a 5-point Likert-type scale where 5 implied Strongly Agree and 1 implied Strongly Disagree.

\section{The sample}

To collect the data to assess the theoretical model proposed in this study a combination of convenience sampling and random sampling was used. The primary sampling unit was the geographical area (cities) in which the target population (higher income, well-qualified individuals) was most likely to be found. Next the secondary sampling units was chosen. In this case, a number of shopping malls in the selected geographical area were selected by means of judgement sampling. Inside each shopping mall 200 randomly selected individual were asked to participate in the study. Respondents qualified to participate in the survey if they had access to the Internet. 


\section{Data analysis}

To assess the reliability of the scores generated by the measuring instruments Cronbach's alpha scores were calculated. An assessment of the discriminant validity of the constructs included in the study was done by means of an exploratory factor analysis. The measurement model was assessed by means of a Confirmatory Factor Analysis (CFA) and the hypotheses were assessed by means of Structural Equation Modelling (SEM) using LISREL 8.80.

\section{Empirical results}

\section{Discriminant validity}

In order to assess the discriminant validity among the independent variables (the different types of risks) in the theoretical model an exploratory factor analysis was conducted. A principal axis factor analysis with an Oblimin rotation yielded the most interpretable factor structure. The results of the exploratory factor analysis revealed that some items measuring some of the risks had to be deleted from the data set due to poor discriminant validity. Several exploratory factor solutions were considered. The most interpretable factor solution was a three-factor solution (Table 1).

Table 1: Exploratory factor analysis results (risk types)

\begin{tabular}{l|c|c|c}
\hline & Personal & Performance & Social \\
\hline PSYCH2 & $\mathbf{0 , 8 6 2}$ & $-0,038$ & $-0,052$ \\
\hline PSYCH4 & $\mathbf{0 , 6 6 1}$ & $-0,020$ & $-0,058$ \\
\hline PSYCH3 & $\mathbf{0 , 6 4 0}$ & 0,013 & $-0,208$ \\
\hline PSYCH1 & $\mathbf{0 , 6 0 4}$ & $-0,049$ & $-0,271$ \\
\hline PHYS4 & $\mathbf{0 , 5 9 7}$ & 0,033 & $-0,114$ \\
\hline PHYS2 & $\mathbf{0 , 4 9 8}$ & 0,136 & 0,010 \\
\hline PERF5 & $-0,099$ & $\mathbf{0 , 7 6 4}$ & $-0,074$ \\
\hline PERF2 & $-0,010$ & $\mathbf{0 , 7 6 4}$ & $-0,045$ \\
\hline PERF1 & $-0,063$ & $\mathbf{0 , 7 4 3}$ & $-0,049$ \\
\hline PERF4 & $-0,166$ & $\mathbf{0 , 7 2 8}$ & $-0,171$ \\
\hline TIME1 & 0,133 & $\mathbf{0 , 7 0 9}$ & 0,018 \\
\hline PERF3 & 0,012 & $\mathbf{0 , 6 8 8}$ & 0,027 \\
\hline TIME2 & 0,244 & $\mathbf{0 , 6 0 2}$ & 0,150 \\
\hline TIME3 & 0,209 & $\mathbf{0 , 4 8 9}$ & 0,149 \\
\hline SOC1 & 0,041 & 0,064 & $\mathbf{- 0 , 8 5 0}$ \\
\hline SOC2 & 0,134 & 0,086 & $\mathbf{- 0 , 7 9 1}$ \\
\hline SOC3 & 0,260 & 0,021 & $\mathbf{- 0 , 6 7 1}$ \\
\hline SOC4 & 0,240 & $-0,020$ & $\mathbf{- 0 , 4 6 4}$ \\
\hline Cronbach alpha & $\mathbf{0 , 8 5 1}$ & $\mathbf{0 , 8 8 2}$ & $\mathbf{0 , 8 8 4}$ \\
\hline
\end{tabular}

Table 1 shows that the items expected to measure Time risk and Performance risk loaded on one factor. An inspection of the items measuring Time risk revealed that they do in fact measure performance-related risks. Examples include: "I am concerned about the delay between ordering and receiving books bought at XXX"; XXX may not have my book in stock and I will have to wait for them to get it in stock". Against this background the resultant factor was named Performance risk. Items used to measure Time risk were thus modelled as additional measures of Performance risk.

Table 1 also shows that items expected to measure Physical risk and Psychological risk loaded on one factor and was labelled Personal risk. Due to poor discriminant validity among some of the items measuring the original risk perceptions only three risk perceptions remained namely Personal risk, Performance risk and Social risk. The remaining 18 items (measuring the three risk types) were then subjected to a reliability assessment using Cronbach's Alpha and a test of Multivariate Normality.

\section{Reliability results}

The generally accepted norm for a score to be regarded as reliable (in this instance internal consistency) is 0.70 (Nunnally \& Bernstein, 1994). All three the reliability coefficients for the three re-configured risk constructs exceed the customary cut-off of 0.7 (see Table 1 ). It can thus be concluded that these scores and the instruments used to measure the constructs investigated in this study can be described as very reliable

\section{Multivariate normality}

The selection of an estimation method in structural equation modelling is influenced by distributional properties of the data (Hair et al., 2006). Therefore, before the confirmatory factor analysis was conducted the multivariate normality of the data was assessed. The null hypothesis considered was that the data demonstrate sufficient evidence of multivariate normality. To assess the multivariate normality of the data (skewness and kurtosis), LISREL 8.80 was used. The test result (skewness and kurtosis $\chi^{2}=1275,51 ; p<0,000$ ) revealed that the assumption of multivariate normality did not hold for this data set, suggesting that the null hypothesis had to be rejected. Due to the violation of the assumption of multi-variate normality the more conventionally used Maximum Likelihood (ML) could not be used (Jöreskog \& Sörbom, 2008). Under such circumstances Satorra and Bentler $(1988$; 1994) proposed that the Robust Maximum Likelihood (RML) estimation method be used. The confirmatory factor analyses model fit statistics of the Robust Maximum Likelihood analysis $\left(\chi^{2}=226,44\right.$; $\mathrm{p}=0,000 ; \mathrm{df}=132 ; \mathrm{RMSEA}=0,060 ; \mathrm{ECVI}=1,530)$ suggested that the measurement model for the perceived risks associated with intention to purchase online on a branded web site fitted the data fairly closely.

\section{The influence of perceived risk on purchase intention}

The primary objective of the study was to assess the direct influence of perceived risks on consumer's intention to purchase on a branded web site. A structural equation model was specified following the exploratory factor analysis. The model contained three risks, namely Personal risk, Performance risk and Social risk as potentially influencing Intentions to purchase on a branded web site. 
To assess the influence of risk perceptions on intentions to purchase on a branded web site the following hypothesis was considered:

$\mathrm{H} 0^{1}$ : The influence of perceived risk on intentions to purchase is equal to zero

The results of the structural modelling analysis shown in Figure 1 reveal that both Performance risk (path coefficient: $-0,30$; t-value: $-3,09 ; \mathrm{p}<0,01)$ and Social risk (path co-efficient: $-0,24$; t-value: $-2,19 ; \mathrm{p}<0,05$ ) exert a strong negative influence on Intentions to purchase on a branded web site. Personal risk, however, do not impact on Intentions to purchase on a branded web site. As a result of these empirical results Hypothesis $\mathrm{H}^{1}$ had to rejected in respect of Performance risk and Social risk. The fit indices $\left(\chi^{2}=253,95 ; \mathrm{p}=0,0088 ; \mathrm{df}=203 ; \chi^{2} / \mathrm{df}: 1,24 ; \mathrm{RMSEA}=\right.$ 0,0355 ; ECVI $=1,779$ ) indicate that the model provides a close fit with the sample data.

\section{The mediating effect of brand knowledge}

The secondary objective of this study was to consider the potential effect of brand knowledge as a mediating variable for the effects of Performance Risk and Social Risk on Intentions to Purchase. The models in Figure 2 and 3 were used to assess partial and full mediation respectively.

\section{Partial mediation: Brand knowledge}

In the case of the partial mediation of brand knowledge on the effects of Performance Risk and Social Risk on Intentions to Purchase the following null hypotheses were considered:

$\mathrm{HO}^{2}$ : The partial indirect effect of Performance Risk on Intentions to Purchase is equal to zero

$\mathrm{H}^{2 \mathrm{a}}$ : The partial indirect effect of Performance Risk on Intentions to Purchase is not equal to zero

$\mathrm{H}^{3}$ : The partial indirect effect of Social Risk on Intentions to Purchase is equal to zero

$\mathrm{H} 0^{3 \mathrm{a}}$ : The partial indirect effect of Social Risk on Intentions to Purchase is not equal to zero

The LISREL results summarised in Table 2 indicate that, if a significance level of $1 \%$ is used, brand knowledge does act as a partial mediating variable between Performance Risk and Intentions to purchase on a branded web site $(\mathrm{t}=-3.598$; $\mathrm{p}<0.01)$. More specifically, knowledge of the brand will enhance the likelihood of purchasing on a branded web site by lowering concerns about Performance Risk. Brand knowledge, however does not partially mediate (p-value > $0,05)$ the impact of Social Risk on Intentions to Purchase on a branded web site. Against this background there is sufficient evidence to reject $\mathrm{H}^{2}$ but $\mathrm{H}^{3}$ cannot be rejected.

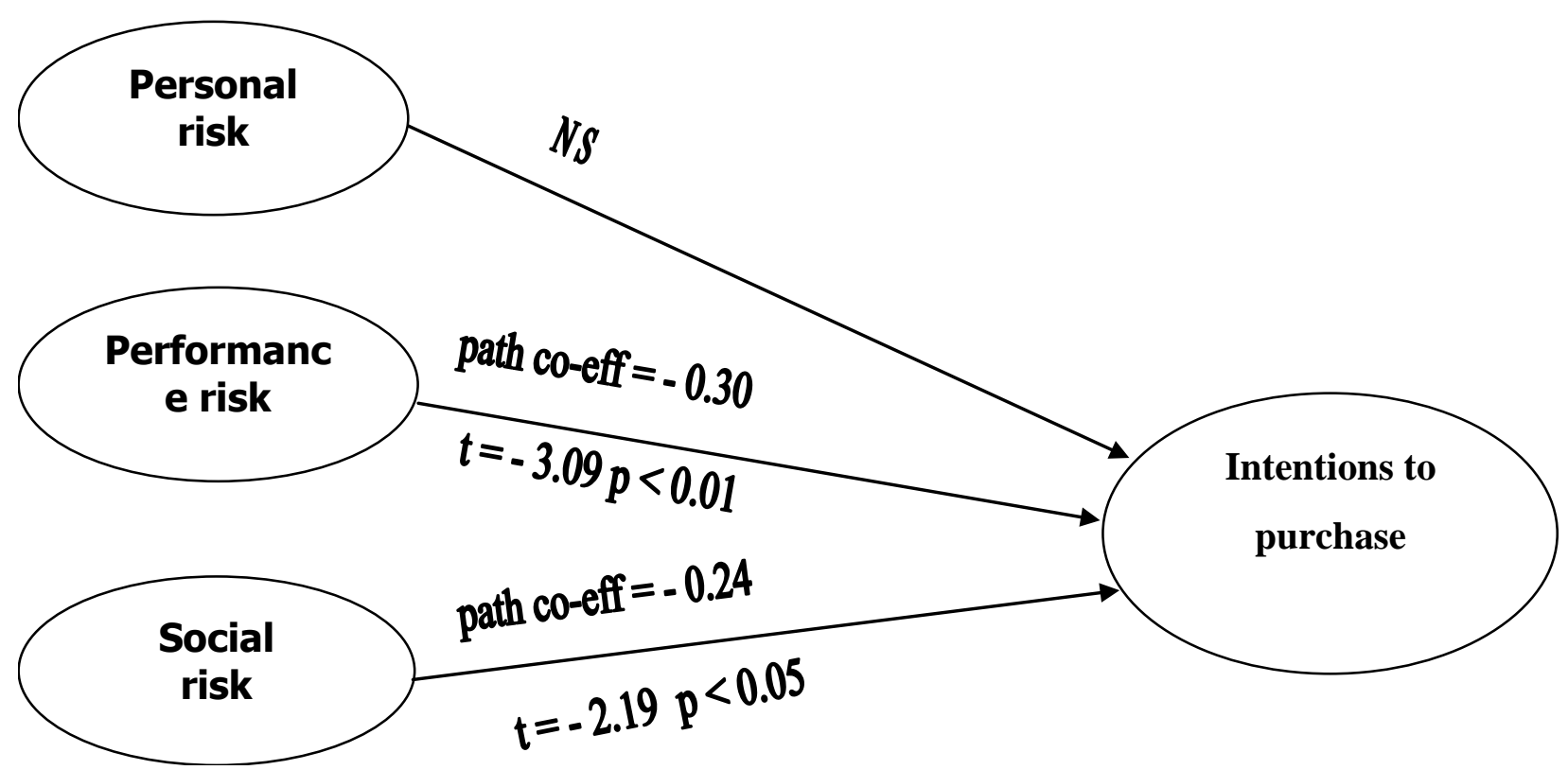

Figure 1: The influence of risk perceptions on intentions to purchase online on a branded website 


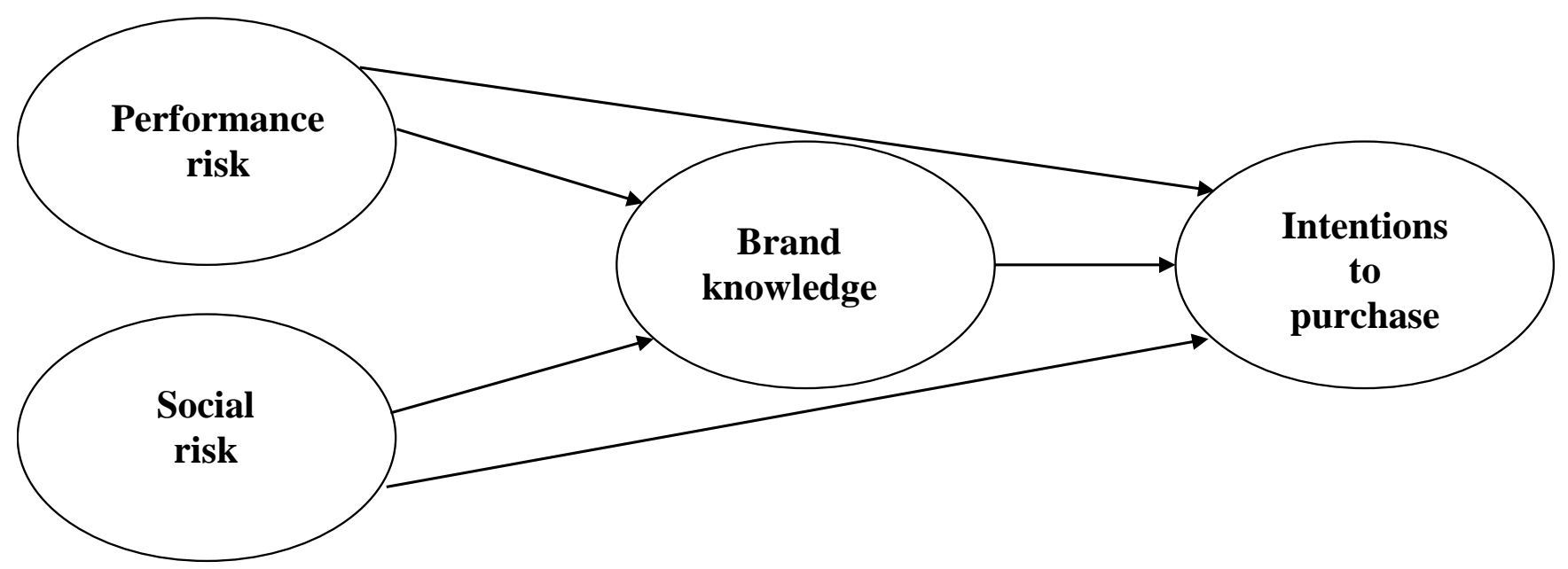

Figure 2: Partial mediation

\section{Full mediation: Brand knowledge}

To assess the full mediating effect of brand knowledge on the effects of Performance Risk and

Social Risk on Intentions to Purchase the following null hypotheses were considered:

$\mathrm{H}^{4}$ : The full indirect effect of Performance Risk on Intentions to Purchase is equal to zero

$\mathrm{H}^{4 \mathrm{a}}$ : The full indirect effect of Performance Risk on Intentions to Purchase is not equal to zero

$\mathrm{H} 0^{5}$ : The full indirect effect of Social Risk on Intentions to Purchase is equal to zero

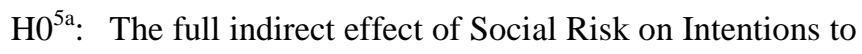
Purchase is not equal to zero

When the full mediation model is specified (Table 3), the conclusions are the same as in the case of partial mediation. Brand knowledge mediates the relationship between Performance Risk and Intentions to Purchase $(t=-4.130$; $p$ value $<0,01)$ but not that between Social Risk and Intention to purchase ( $\mathrm{p}$-value $>0,05$ ). Thus, $\mathrm{H}^{4}$ should be rejected but $\mathrm{H} 0^{5}$ cannot be rejected.

Thus, when the intervening variable (brand knowledge) is added to the model the negative impact of Performance Risk on Intentions to Purchase (Figure 1) all but disappears.

Table 2: Brand knowledge as intervening variable: Partial mediation

\begin{tabular}{l|c|c}
\hline & Performance risk & Social risk \\
\hline Intention to purchase & $-0,210$ & 0,027 \\
& $(0,058)$ & $(0,044)$ \\
& $-3,598$ & 0,620 \\
\hline
\end{tabular}

Table 3: Brand knowledge as intervening variable: Full mediation

\begin{tabular}{l|c|c}
\hline & Performance risk & Social risk \\
\hline Intention to purchase & $-0,249$ & 0,008 \\
& $(0,060)$ & $(0,048)$ \\
& $-4,130$ & 0,176 \\
\hline
\end{tabular}

\section{Conclusion}

Based on the results of this study, consumers perceived three types of risk associated with online purchase intention, namely Performance, Social, and Personal risk.

It was found that both Performance risk and Social risk exert a strong negative influence on Intentions to purchase on a branded web site. Personal risk, however, do not impact on Intentions to purchase on a branded web site. Furthermore Brand knowledge does act as an intervening variable between Performance risk and Intentions to buy on a branded web site. Brand knowledge, however does not mediate the impact of Social risk on intentions to buy on a branded web site.

It was also found that when shopping on a branded website, a consumer's ability to recall and recognise, as well as carry positive thoughts, feelings, images, and beliefs concerning the online retailer (brand knowledge) will aid in increasing their likelihood of purchase. Also, when shopping on a branded website, the ability of the consumer to recall and recognise the online retailer as a brand can lower their perceived performance risk, which in-turn will increase their likelihood of purchase. 


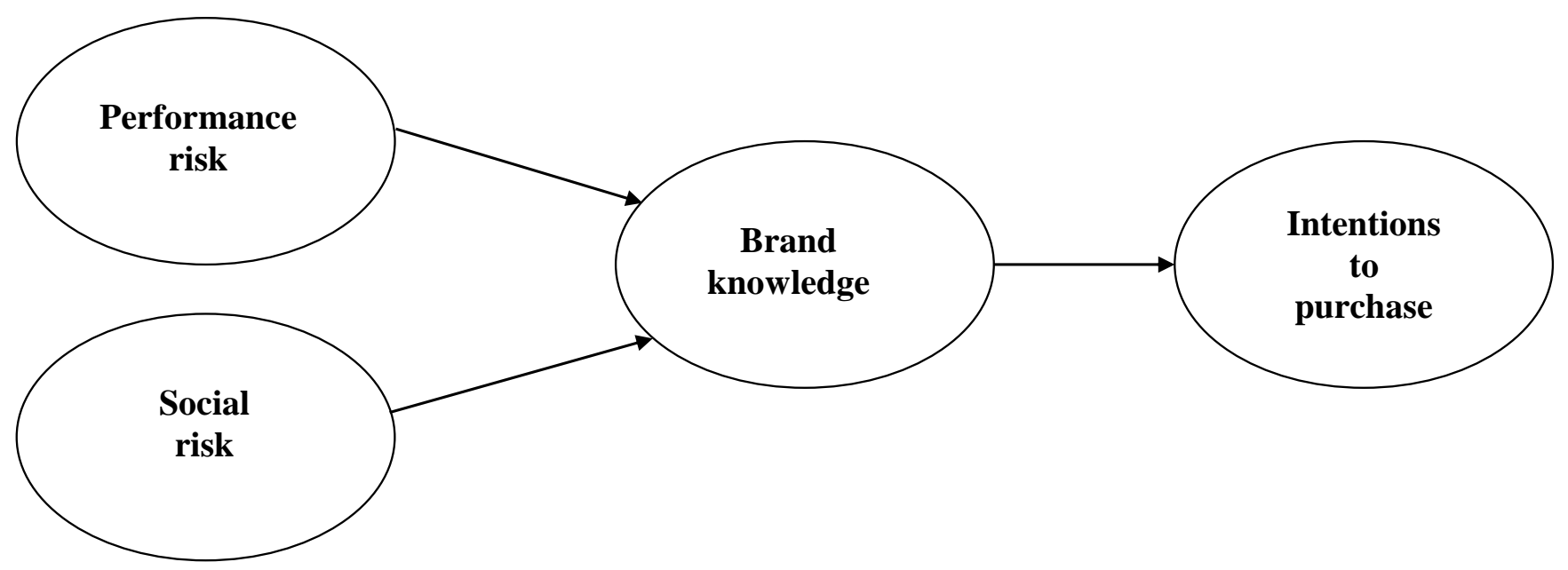

Figure 3: Full mediation

These findings are very similar to those reported regarding risk perceptions when a shopping on a generically (nonbranded) web site (Boshoff et al., 2009). Of the different types of risk perceptions investigated in the generic web site study, only Performance risk (also called Functional risk by some authors) influences the intentions to purchase on a generically-branded website. In that study it was found that that brand image (not brand knowledge) mediates the influence of Performance risk on Intentions to purchase on a generically-branded website.

\section{Managerial implications}

In broad terms the results of the study are consistent with the consumer decision-making literature that suggests that consumers tend to develop their own strategies in order to reduce the risk associated with a particular purchase (Schiffman \& Kanuk, 2004: 198). Such risk reduction strategies (or risk relievers) enable consumers to act with increased confidence when making purchasing decisions.

The finding on brand knowledge relates to consumers' natural tendency to trust well-known brand names as a substitute for the familiarity and certainty of the outcome of the purchase (Schiffman \& Kanuk, 2004: 198). The brand implies an assurance of a standard of quality, dependability, performance and service.

When using branding as a means to manage risk perceptions a web site manager can embark on an Integrated Marketing Communication campaign to develop the brand knowledge and associate the desired characteristics with the brand. Performance signals can be sent to consumers via traditional channels and reinforced when they visit the website through design and content. Hanson and Kalyanam (2007: 195), for instance, highlight the importance of integration amongst communication channels when referring to the evocation of online responses required to coordinate traditional and online brand development mediums. They identify two aspects of online communication that convey brand meaning namely imagery and functional performance-related information.

However, as information requirements are subjective a web site manager should design a system that can be tailored to individual needs. Imagery refers to the brand personality and in turn, the set of human characteristics associated with the brand (Hanson \& Kalyanam, 2007: 194). Careful consideration should thus be given to aspects of digital content to ensure the consistent communication of the desired brand image.

Creating recall and recognition, positive thoughts, feelings, images and beliefs concerning an online retailer means creating a positive online retail experience. This experience can be engendered by synchronising the consumer's needs and the shopping environment, in this case, the website. Methods for achieving this include:

- Drawing attention to steps that the consumer should follow to effectively complete a purchase.

- Inserting visual design that conveys the company culture and positioning.

- Adding imagery and representations that clarify and enhance the product and service offerings.

- Ensure visible corporate identity/logo on delivery packaging.

- $\quad$ Send a free branded book mark on delivery of product order, in this way the consumer is exposed to the brand identity after purchase and off the internet.

- Increasing awareness through (SEO) Search Engine Optimization strategies. 
- Monthly newsletters enhanced by corporate identity consistent with website experience for consumer brand to memory repetition.

- Reward programmes whereby the consumer has an incentive to purchase from your particular online website as opposed to a brick and mortar retailer or another online retailer. Reward programmes also provide a platform with many opportunities for brand awareness and image strategies.

Finally, Hanson and Kalyanam (2007: 239) emphasise that an important aspect of online retailing involves the perceived credibility of the retailer. The authors list several guidelines a retailer could refer to in order to enhance perceived credibility:

- Make it easy to verify the accuracy of the information on the site.

- Show that there is a real organisation behind the site.

- Highlight the expertise of the organisation and in the content and services provided.

- Emphasise the integrity of the people responsible for the site.

- Make it easy to contact the retailer.

- The design needs adhere to the appropriate usability, should be up-to-date and error-free.

- $\quad$ Avoid excessive advertising on the site.

\section{Acknowledgement}

The assistance of Dr Gerhard Mels (SSI) in analysing the data is gratefully acknowledged.

\section{References}

Bauer, R.A. 1960. 'Consumer behaviour as risk taking'. In Cox, D.F. 1967. Risk taking and information handling in consumer behaviour. Boston: Harvard University Press, p.p. 23-33.

Boshoff, C., Schlechter, C. \& Ward, S. 2009. 'The mediating effect of brand image and information search intentions on the perceived risks associated with online purchasing on a generically-branded website,' Management Dynamics, 18(4): 18-27.

Chen, R. \& He, F. 2003. 'Examination of brand knowledge, perceived risk and consumers` intention to adopt an online retailer', TQM \& Business Excellence, 14(6): 677-693.

Chen, Y.H. \& Barnes, S. 2007. 'Initial trust and online purchaser behaviour', Industrial Management and Data Systems, 107(1): 21-36.

Cox, D.F. 1967. Risk taking and information handling in consumer behaviour. Boston: Harvard University Press.
Cox, D.F. \& Rich, S.U. 1964. 'Perceived risk and consumer decision making - The case of telephone shopping', Journal of Marketing Research, 1: 32-39.

Delgado-Ballester, E. \& Hernández-Espallardo, M. 2008. 'Building online brands through brand alliances in Internet', European Journal of Marketing, 42 (9/10): 954 - 976.

Dowling, G. R. \& Staelin, R. 1994. 'A model of perceived risk and intended risk-handling activity', Journal of Consumer Research, 21(June): 119-134.

Dunn, M.G., Murphy, P.E. \& Skelly, G.U. 1986. 'Research note: The influence of perceived risk on brand preference for supermarket products', Journal of Retailing, 62(2): 204216.

Esch, F-R., Langner, T., Schmitt, B.H. \& Geus, P. 2006. 'Are brands forever? How brand knowledge and relationships affect current and future purchases', Journal of Product and Brand Management, 15(2): 98-105.

Forsythe, S.M. \& Shi, B. 2003. 'Consumer patronage and risk perceptions in internet shopping', Journal of Business Research, 56: 867-875.

Gupta, A., Su, B. \& Walter, Z. 2004. 'Risk profile and consumer shopping behaviour in electronic and traditional channels', Decision Support Systems, 38 (3): 347 - 367.

Hair, J.F., Black, W.C., Babin, B.J., Anderson, R.E. \& Tatham, R.L. 2006. Multivariate data analysis, $6^{\text {th }}$ Edition. Upper Saddle River, New Jersey: Pearson Prentice Hall.

Hanson, S. \& Kalyanam, K. 2007. Internet marketing and eCommerce. Ohio: Thomson South Western.

Hassan, A.M., Kunz, M.B., Pearson, A.W. \& Mohamed, F.A. 2006. 'Conceptualisation and measurement of perceived risk in online shopping', Marketing Management Journal, 16(1): 138-147.

Havlena, W.J. \& DeSarbo, W.S. 1991. 'On the measurement of consumer risk', Decision Sciences, 22(4): 927-939.

Hoffman, K.D. \& Bateson, J.E.G. 1997. Essentials of services marketing. London: The Dryden Press.

Horton, R.L. 1976. 'The structure of perceived risk: Some further progress', Journal of the Academy of Marketing Science, 4(4): 694-706.

Hsu, H-C., Lai, C-S. \& Chen, C-H. 2007. 'Extrinsic cue of warranty by selling through a reputable website', Journal of Advertising Research, June: 158-164.

Huang, W-Y., Schrank, H. \& Dubinsky, A.J. 2004. 'Effect of brand name on consumers' risk perceptions of online shopping', Journal of Consumer Behaviour, 4(1): 40-50. 
IMRG. 2007. Quoted on

http://www.totalwebsolutions.com/pages/pages_business/ec om-stats.pdf .Accessed on 15 June 2009.

Jacobs, B. \& De Klerk, H.M. 2007. 'Understanding female consumers' risks perception for apparel purchasing on the internet', Journal of Family, Ecology and Consumer Sciences, 35: 47-58.

Jarvelainen, J. \& Puhakainen, J. 2004. 'Distrust of one's own web skills: A reason for offline booking after online information search', Electronic Markets, 14(4): 333-343.

Jöreskog K.G. \& Sörbom, D. 2008. 'Non-normal data'. Scientific Software International. [online] URL: http://www.ssicentral.com/lisrel/resources.html, Accessed March 2008.

Lu, H.P., Hsu, C.L. \& Hsu, H.Y. 2005. 'An empirical study of the effect of perceived risk upon intention to use online applications', Information Management and Computer Security, 13(2), pp. 106- 120.

Mayo, D.T., Helms, M.A. \& Inks, S.A. 2006. 'Consumer internet purchasing patterns: A congruence of product attributes and technology', International Journal of Intrnet Marketing and Advertising, 3(3): 271-298.

Mitchel, V.W. \& Boustani, P. 1992. 'Consumer risk perceptions in the breakfast cereal market', British Food Journal, 94(4): 17-26.

Nielsen, A.C. 2005. 'Global consumer attitudes towards online shopping'. [online] URL:

http://www2.acnielsen.com/reports/documents/2005_cc_onl ineshopping.pdf. Accessed April 2008.

Nunnally, J.C. \& Bernstein, I.H. 1994. Psychometric theory. ( $3^{\text {rd }}$ Edition). New York: McGraw- Hill.

Olshavsky, R.W. \& Granbois, D.H. 1979. 'Consumer decision-making - fact or fiction?' Journal of Consumer Research, 6 (September): 93-100.

Parasuraman, A., Zeithaml, V. A. \& Berry, L.L. 1985. 'Problems and strategies in services marketing', Journal of Marketing, 49 (Spring): 33-46.

Roselius, T. 1971. 'Consumer rankings of risk reduction methods', Journal of Marketing, 35: 56-61.

Satorra, A. \& Bentler, P.M. 1988. 'Scaling corrections for chi-square statistics in covariance structure analysis'. In Proceedings of the Business and Economic Statistics Section of the American Statistical Association, American Statistical Association, VA. pp. 308-313.
Satorra, A. \& Bentler, P.M. 1994. 'Corrections to test statistics and standard errors in covariance structure analysis'. In Von Eye, A \& Clogg, C.C. (Eds.). Latent variable analysis: Applications to developmental research. Newbury Park: Sage, p.p. 399-419.

Schiffman, L.G. \& Kanuk, L.L. 1997. Consumer behavior, $6^{\text {th }}$ Edition. Englewood Cliffs: Prentice Hall.

Schiffman, L.G. \& Kanuk, L. L. 2004. Consumer Behaviour. New Jersey: Pearson Prentice Hall.

Solomon, M.R. 1992. Consumer behavior. London: Allyn and Bacon.

Statt, D.A. 1997. Understanding the consumer: A psychological approach. London: MacMillan Business.

Stewart, K. \& R. Malaga .2009. 'Contrast and assimilation effects on consumers' trust in Internet companies', International Journal of Electronic Commerce 13(3): 71-93.

Swinyard, W.R. \& Smith, S.M. 2003. 'Why people (don't) shop online: A lifestyle study of the internet consumer', Psychology and Marketing, 20(7): 567-597.

$\mathrm{Su}$, B. 2008. 'Characteristics of consumer search on-line: How much do we search?' International Journal of Electronic Commerce Research, 13(1): 109-129.

Suh, B. \& Han, I. 2003. 'The impact of customer trust and perception of security control on the acceptance of electronic commerce', International Journal of Electronic Commerce, 73: 135-161.

Tan, S.J. 1999. 'Strategies for reducing consumers' risk aversion in internet shopping', Journal of consumer marketing, 16 (2): 163-180.

Tan, Y.-H. , \& Thoen, W. 2000-2001. 'Toward a generic model of trust for electronic commerce', International Journal of Electronic Commerce, 5 (2): 61-74.

Ueltschy, L.C., Krampf, R.F. \& Yannopoulos, P. 2004. 'A cross national study of perceived consumer risk towards online (internet) purchasing', The Multinational Business Review, 12(2): 59-82.

Wood, C.M. \& Sheer, L.K. 1996. 'Incorporating perceived risk into models of consumer deal assessment and purchase intent', Advances in Consumer Research, 23: 399-404.

Yang, B., Lester, D. \& James, S. 2007. 'Attidudes towards buying online as predictors of shopping online for British and American respondents', Cyberpsychology and Behaviour, 10(2): 198-203. 


\section{APPENDIX A \\ SCALE ITEMS USED}

\section{INTENTIONS TO PURCHASE}

INTENT1 I would purchase a book from XXXX net if needed

INTENT2 If XXXX net has the product I need, I will probably purchase it from them

INTENT3 I will recommend XXXX net to friends and relatives as a place to purchase books

INTENT4 I wouldn't mind purchasing a book from XXXX net on behalf of someone else

\section{BRAND KNOWLEDGE}

BRAND1 I feel it is safe to purchase online at XXXX net

BRAND2 If I were to purchase online I will recall XXXX net as a place to purchase books

BRAND3 I have previously seen or heard of XXXX.net

BRAND4 I feel that one is likely to have a satisfying experience when shopping on XXXX net

BRAND5 I am familiar with the XXXX.net brand

\section{PEFORMANCE RISK}

PERFORM1 I am concerned that the book delivered may not be exactly as it appeared when displayed on the computer screen

PERFORM2 I don't like the fact that I can't feel, read, or/and experience the book before purchasing during online shopping

PERFORM3 It is difficult to ascertain the characteristics of the book such as quality, weight, and size just by looking at its cover and back page provided on the computer screen

PERFORM4 I am concerned that the rating of the book is a false indication of the actual read

PERFORM5 I am concerned that the book will not be what I thought it would be

\section{FINANCIAL RISK}

FINANCE1

FINANCE2

FINANCE3

FINANCE4

\section{TIME RISK}

TIME1

TIME2

TIME3

TIME4

TIME5

\section{SOCIAL RISK}

SOCIAL1

SOCIAL2

SOCIAL3

SOCIAL4
It is not safe to give my credit card number when I order at XXXX net

XXXX net may not send the book after payment

I am concerned about the ultimate price of the book when shopping at XXXX net because there might be hidden costs.

I am concerned that my financial details might not be adequately protected if I shop at XXXX net

\section{PHYSICAL RISK}

PHYSICAL1 I am concerned that shopping at XXXX net could lead to eyestrain because of frequent exposure to computer screen during shopping

PHYSICAL2 I am concerned about viruses infecting my computer while I shop at XXXX net

PHYSICAL3 I am concerned about getting carpel tunnel syndrome (pain in wrist) while shopping online at XXXX net

PHYSICAL4 I am concerned that shopping on XXXX.net could lead to back pain because of my posture when sitting in front of the computer for extended periods of time

\section{PSYCHOLOGICAL RISK}

PSYCH1 I think shopping at XXXX net will harm my self-image

PSYCH2 The thought of shopping at XXXX net causes me to experience unnecessary tension

PSYCH3 The thought of shopping at XXXX net makes me feel uncomfortable.

PSYCH4 Shopping at XXXX net will lead to too much social isolation 